\title{
RIQUEZA DE IMÁGENES EN RAIMUNDO LULIO. EL EJEMPLO DE LIBRO DEL AMIGO Y DEL AMADO
}

\author{
José María Soto Rábanos \\ Instituto de Historia. CSIC. Madrid
}

\section{RESUMEN}

En este trabajo reflexiono sobre la capacidad de imaginar de Raimundo Lulio, que le permite introducir personajes y situaciones sin obstáculos en sus narraciones. Después de unas consideraciones generales, examino el desarrollo de la capacidad imaginativa de Lulio en la obra Libro del amigo y del Amado mediante el análisis de algunas imágenes de especial relieve. El lector de esta obra luliana puede constatar que su protagonista, el amigo (el cristiano, Lulio mismo), mantiene el amor en un hervidero de sensaciones en un continuo ir y venir de la potencia sensitiva a la raciocinativa, a través de la potencia imaginativa. La mística luliana es dinámica, con un cierto grado de masoquismo.

Palabras clave: Raimundo Lulio, imágenes, amigo, amor, amado, misticismo, sensibilización.

\begin{abstract}
In this article I think over the capacity of Raimond Llull to imagine, that allows him to introduce characters and situations in his narratives without obstacles. After some general considerations, I pay attention to the development of the imaginative capacity of Lulio in his work «Libro del amigo y del Amado» (Book of the friend and the Beloved), through the analysis of some images of importance. The reader of this work from Llull may note that his main character, the friend (the Christian, Llull himself), maintains the love in a swarm of sensations, in a continuous movement between the sensitive and the raciocinative, through the imaginative faculty. The mystic of Llull is dynamic, with a certain degree of «masochism».
\end{abstract}

Key words: Raimond Llull, images, friend, love, beloved, mysticism, sensitising.

\section{LA IMAGINACIÓN DE RAIMUNDO LULIO}

Todos cuantos han estudiado a Raimundo Lulio destacan su fuerza imaginativa. Martín de Riquer recoge este sentir en una frase sencilla: «Raimundo disponía de una brillante imaginación» ${ }^{1}$. No se refiere, claro está, al lugar que ocupaba la imaginación en la filosofía de Raimundo, al puesto de la imaginación en el sistema del arte luliano; se refiere a la personalidad de Raimundo, a su capacidad imaginativa, a su facilidad de encontrar imágenes, a su tendencia hacia la búsqueda de soluciones distintas (fuera de las que se barajaban en las instituciones de la cristiandad occidental), a su potencial de percepción, de asimilación y de comunicación de hipótesis y de tesis. 
Si partimos del lugar que ocupa la imaginación en el sistema del arte luliano ${ }^{2}$ y nos adentramos por los vericuetos de su arte, de su sistema, nos daremos cuenta de que este juego imaginativo es lo que hace que la obra de Lulio sea atractiva y sugerente, más que conclusiva. Quiero decir que nos presenta las ideas con tal cúmulo de imágenes, y de imágenes tan sugerentes, que induce al estudio y análisis, y enriquece la argumentación original, si bien a la hora de extraer conclusiones, de fijar el contenido del ergo..., el argumento no acaba de cerrarse bien; la proposición se nubla, se difumina ${ }^{3}$. En todo caso, la imaginación permite a Lulio hallar caminos novedosos, no vistos, no pensados por otros de su época; con el peligro, incluso, de no ser entendido ni comprendido.

Si en el libro del Gentil y los tres sabios el diálogo está presidido por la inteligencia, en parangón, habrá que decir que la vida y la actividad de Raimundo Lulio están presididas por la imaginación. Imaginación y rica vida interior. Está imaginando constantemente, dando vueltas y más vueltas a su imaginación, en continua búsqueda. Cuando halla su arte, que debía ser para todos, y era para él, el non plus ultra, sigue en busca de los modos adecuados, de los más adecuados para facilitar su comprensión y difusión. De otra parte, sólo con una imaginación fuerte, desbordante, pudo Lulio abarcar saberes tan diversos y plasmarlos por escrito de manera tan rica de matices. Sin una imaginación tan poderosa, no cabe explicar su anticipación histórica en campos tan diversos: sistema filosófico, apostolado social, metodología científica,... En todo lo que tocó puso un sello de novedad.

Y no se trata simplemente de imágenes nuevas, o sólo de imágenes nuevas, ni de mera contemplación de imágenes o de recrearse en ellas; es decir, no se trata de retórica ${ }^{4}$, sino de la implicación de las imágenes en los argumentos, de modo que se capte mejor su viabilidad, que lleguen mejor a la inteligencia, memoria y voluntad de sus lectores y oyentes. Lulio eleva la importancia de la imagen, que viene a ser utilizada por él como argumento. Se diría que no es sólo una ayuda para la intelección, sino un camino argumentativo, válido por si mismo, amén de necesario, para entender, retener y amar las esencias mismas de las proposiciones ${ }^{5}$. Lulio tiene claro que lo que no se sensibiliza, no se imagina; y lo que no entra por la imaginación ni se conoce ni se ama; es decir, no llega a la intelección, a la memoria y a la voluntad. Me vienen aquí a la memoria unas palabras de nuestro homenajeado amigo Joaquín Lomba Fuentes, que pronunció en el $\mathrm{XI}^{\circ}$ Congreso Internacional de Filosofía Medieval (Porto, 26-31 de agosto de 2002) en la exposición de su ponencia sobre: Razón e imaginación en la estética musulmana medieval, palabras que me parecen aplicables enteramente al método de razonamiento luliano: «Puesto que el Uno es inalcanzable por la razón, hay que utilizar la imaginación para expresarlo» ${ }^{6}$.

En efecto, la imaginación es la primera y mejor inspiración, la primera fuente de Lulio. No se enreda, ni nos enmaraña, con ideas; sus ideas son sencillas, simples; son ideas máximas: ser, bien, verdad, justicia, amor, etc. Pero sí se complica y nos complica con imágenes, que uti-

2 Celestino Aos Braco, «La imaginación en el sistema de Ramón Llull», en Estudios Lulianos 23 (1979) 155 183. Al final del estudio (pp.179-181), el autor ofrece algunas breves consideraciones sobre el genio imaginativo de Ramón Llull.

3 Tomás y Joaquín Carreras y Artau; Historia de la filosofia española: filosofía cristiana de los siglos XIII al XV, vol. I, Madrid, 1939, p. 258, observan que Raimundo Lulio «no se sujeta a ninguna regla... Todas esas cualidades fluyen de un fondo inconsciente de indisciplina, que incapacita radicalmente a Lull para toda organización estable».

4 Ni me parece que a Lulio se le pueda destacar especialmente como un escritor retórico, aunque sea, en efecto, un buen retórico. Es decir, no trata de hacer retórica; simplemente, sabe utilizarla muy bien.

5 Una frase que leo en el libro de Sebastià Trias Mercant: Ramon Llull. El pensamiento y la palabra, El Tall Editorial, Mallorca, 1993, p. 10, me reafirma en la observación hecha: «La originalidad de la Razón luliana radicaría [se lee: redicaría] en la intervención del lenguaje, no tanto como medio o instrumento de expresión cuanto como argumento».

6 No puedo asegurar que la cita sea literal; pero creo ser fiel al sentido. La transcribo tal como la recuerdo. 
liza como el método único asequible para penetrar en las ideas, para comprenderlas intelectivamente y descansar en ellas, gozando de su posesión mediante la memoria (rescate del olvido, presencia) y la voluntad.

El hecho de que Lulio elabore su arte con tantas proposiciones para la cómprensión suya y ajena demuestra que poseía mucha fuerza sensitiva y que tenía los sentidos muy abiertos, muy en acto: vista penetrante, oído atento, gusto delicado, olfato agudo, tacto fino y verbo listo. Con otras palabras, tenía penetración en la vista, atención y presteza en el oído, delicadeza en el gusto, agudeza en el olfato, finura en el tacto, facilidad en el habla y un sentido común extraordinario.

No he tratado de averiguar si hay en Raimundo Lulio un orden de principalidad en la captación sensitiva de imágenes: vista, oído, tacto, olfato, gusto, habla. Por el número de veces que acude al sentido de la vista y por la categoría funcional que atribuye al ver, habría que decir que es el principal, el más cercano al entendimiento; el entendimiento ve ${ }^{7}$. Pero he notado que hay captación de imágenes por varios sentidos a un tiempo; que se puede hablar de gusto de la lectura por la vista o por el oído: que se puede leer o escuchar, solo o en compañía, comiendo o en acto aparte; leer y meditar oyendo música sagrada; meditar y pasear al tiempo que se huele en el jardín o en el campo; que el olor lleva al gusto, etc. Es decir, Lulio combina sentidos para conseguir una imaginación más rica, más y mejor dotada, con mayores y mejores posibilidades de comprensión y de argumentación.

Fue Lulio un sabio imaginativo, tanto o más, incluso, que un sabio inteligente. Tuvo, y nadie lo pone en duda, una buena y amplia formación, aunque no sepamos bien dónde, qué, cómo, con quiénes y durante cuanto tiempo estudió. Demuestra tener grandes conocimientos en todas o casi en todas las disciplinas del saber de su tiempo, aunque la intensidad de sus conocimientos no sea máxima en una disciplina determinada: filosofía, teología, literatura, derecho... No serán pocos los que le superen en tal o cual disciplina, pero serán muy pocos, si es que los hay, que le superen en el conjunto de su obra; y seguro que nadie le supera en capacidad imaginativa. Nadie sensibilizó como él la situación eclesial y social, y nadie imaginó como él modos y métodos para solucionar los problemas teóricos y prácticos de la situación; y ello sin descuidar el camino de la difusión de su manera de ver la realidad y de los remedios por él imaginados para dar solución a la problemática de esa realidad.

¿Fue Lulio un utópico, un iluso? Me parece que cuando la imaginación se aplica o se ejerce para la solución de problemas prácticos, de la convivencia, no tiene por qué llevar a milenarismos, pero sí puede encaminar hacia utopías. Lo de la imaginación al poder, aparte de otras connotaciones, no deja de ser un grito utópico (sin lugar real), aunque también sea verdad que el progreso necesita cierta carga de utopía, en cuanto la utopía es un motor del progreso. De la metáfora número 4 del Libro del amigo y del Amado, podría deducirse que Lulio soporta una carga de ilusión, y de utopía, por encima de lo razonable. En una visión negativa de los males del mundo, Lulio se muestra a la espera de que el agua, «que tiene por costumbre discurrir hacia abajo», discurra hacia arriba, no per accidens, sino «por su naturaleza». Claro es que también se puede interpretar el texto de la metáfora con un matiz pesimista, de falta de esperanza por parte de Lulio en el futuro del hombre. Se podría entender en el sentido de que no cesarán las tinieblas, ni los caminos infernales, ni llegará el día en que el agua suba hacia arriba o el día en que los inocentes sean mayoría o en que el amigo se sienta orgulloso de morir por el Amado y languidezca de amor. Pero esta interpretación no es, a mi entender, aceptable dentro del pensamiento luliano; comporta un pesimismo que no encaja en su Ars. La respuesta es, a mi entender, que Lulio se maneja bien dentro de los parámetros de la utopía ${ }^{8}$.

7 Metáfora 335 del Libro del amigo y del Amado: «Oía el amigo vituperar a su Amado, y en este vituperio el entendimiento veía...».

8 «Lloraba el amigo, y decía: ¿Cuándo cesarán las tinieblas en el mundo, para que cesen los caminos infernales? Y el agua, que tiene por costumbre discurrir hacia abajo, ¿cuándo llegará la hora en que, por su naturaleza, 
Por otra parte, la imaginación se puede ejercitar dentro de las discusiones filosóficas con el fin de presentar argumentos sutiles; y se puede poner en acto para tratar de obtener soluciones prácticas, es decir, para trasladar la teoría a la práctica de la vida cotidiana, para aplicar mejor la justicia, la piedad, la caridad, la esperanza, etc. Se hace uso de la imaginación en la teología, en la filosofía, en la teoría del saber, y en cualesquiera ciencias; como también en la práctica y en la difusión de los conocimientos, en la catequesis, en el apostolado social, en la vida política, en la ejemplaridad.

Considerada globalmente la inmensa obra luliana, es innegable que su autor tenía un concepto «filosófico» alto de la imaginación como potencia del alma humana. Empero, la imaginación aparece en su análisis filosófico como un instrumento sensorial de que se sirve el entendimiento simplemente para fijar las cosas sensibles, como un espejo de las cosas ${ }^{9}$; algo del todo realista, paradójicamente, en tanto en cuanto no va más allá de las mismas cosas, de su materialidad, de su naturaleza material. Parece que se empobrece así aquello de «abrir las puertas a la imaginación»; pero esto es sólo rigor de método. Justamente, la excelencia de la imaginación luliana está en la riqueza, en la capacidad, de fijar lo sensible. La imaginación permite a Lulio introducir personajes y situaciones sin obstáculos en la narración. La imaginación pone el escenario, marca el tiempo y trae a los personajes, sin trabas, en cada momento.

\section{LIBRO DEL AMIGO Y DEL AMADO.}

Un repaso a la obra Libro del amigo y del Amado o Libro de amigo y Amado, como la titulan otros ${ }^{10}$, nos permite ver la enorme riqueza imaginativa de Lulio en la descripción del amor, en su más alto grado, en su consideración trascendente, que sólo puede darse en el terreno de la fe. Lulio no habla aquí de un amor humano, aunque muchas de las imágenes y contraimágenes le sean perfectamente aplicables. Lulio va más allá, entra en el terreno de la mística cristiana, en el juego de la contemplación en Dios, inserta al cristiano-amigo en Dios-Amado, como el todo al que desea querer, entender y gozar en un recuerdo eterno, que es la presencia permanente, que es la posesión del Amado por el amigo al tiempo que la absorción del amigo por el Amado ${ }^{11}$. Pero mientras esto es el fin, la acción transcurre por el ca-

suba hacia arriba? Y los inocentes, ¿cuándo serán más que los culpables? ¡̇Ah! ¿cuándo se enorgullecerá el amigo de morir por su Amado? Y el Amado, ¿cuándo verá a su amigo languidecer por su amor?»). En las citas, sigo la traducción castellana de Martín de Riquer en la edición de Planeta (Clásicos Universales, Barcelona, 1985), con estudio introductorio de Lola Badía. Esta traducción está hecha sobre la edición vulgata de Salvador Galmés, dentro del Libro de Evast e Blanquerna (Els Nostres Clássics, Barcelona, 1935-1954) en cuatro volúmenes. Creo que es la mejor desde el punto de vista fillológico. Esta edición contabiliza 366 versículos/metáforas en contraste con las 365 que el propio Lulio afirma haber elaborado, una para cada día del año: «Y con la bendición de Dios, Blanquerna empezó su libro, el cual distribuyó en tantos versículos como días tiene el año» (Prólogo, p. 9). Considero que es más acertado distribuir los versículos/metáforas en 365; por lo cual, sigo esta enumeración, que es la de la mayoría de las ediciones. El punto de inflexión está precisamente en esta metáfora número 4; que la edición vulgata, seguida por Planeta, divide en dos, siendo la 4 el grueso de la misma y pasando la última frase ( $\mathrm{Y}$ el Amado...») a formar la metáfora número 5 . En cuanto a las tendencias utópicas de Lulio, cf. Maurice de Gandillac, De quelques utopies (ou semiutopies) de la concorde universelle (Abelard, Lulle, Nicolas de Cues, Postel, Campanella), en Miguel Martínez López (ed.), Literature, Culture and Society of the Middle Ages, IX: Studies in honour of Ferran Valls i Taberner (Barcelona, 1989) 2586-2589. Por mi parte, en el artículo: Lo jurídico en la filosofia luliana, publicado en Revista Española de Filosofia Medieval, 5 (1998) 75-85, llego a la conclusión de que en el ámbito del derecho Lulio juega también a la utopía.

9 Remito al artículo de Celestino Aos Braco, citado en nota 2.

10 Así se titula en la edición citada de Planeta.

11 En la metáfora 55, el amigo desea hacer efectiva la unión con el Amado, pero el Amado lo baja al mundo real del amor, a las fatigas y tribulaciones: «Elevóse el corazón del amigo a las alturas del Amado, a fin de no verse impedido de amar en el abismo de este mundo. Y cuando estuvo con el Amado, lo contempló con dulzura y placer; y el Amado lo descendió a este mundo para que lo contemplase con tribulaciones y fatigas». 
mino, en el tormento sin fin de alcanzar la meta, el infinito imposible, camino en el que la imaginación es motor de las potencias del alma amiga. Un camino hecho de imágenes.

Lola Badía, después de anotar que en la primera parte de la obra abundan las referencias a elementos del mundo real y en la segunda las abstracciones y los juegos de conceptos, con relación a la imaginería se pregunta si «se puede establecer una tipología de la que evoca el mundo físico y la vida material de los hombres, frente a la que ofrece un trasunto simbólico de la experiencia del amor». La respuesta, que afecta también a otros interrogantes puestos de antemano, muestra un claro escepticismo: «Tal vez el supuesto defensor del Libro de amigo y Amado fracase en el intento de sistematizar las respuestas a las preguntas que hemos formulado; los que sostenemos que Llull daba realmente muy poca importancia a los aspectos formales de lo literario, a pesar de servirse de ellos con asombrosa eficacia y poder de seducción, nos sentiremos por lo menos aliviados». Más adelante, la misma autora presenta tres ámbitos de fuentes que le parecen claramente detectables: a) las sugerencias procedentes del tratamiento literario e ideológico del amor profano, que Raimundo Lulio conoció en su juventud de caballero y trovador; b) las sugerencias provenientes de la tradición de la mística cristiana, desde el Cantar de los cantares del Antiguo Testamento hasta Hugo de San Víctor en el siglo XII; y c) las sugerencias que proceden de la propia Arte luliana ${ }^{12}$.

Por mi parte, he tenido claro desde el principio que no entraría en sistematizaciones de la imaginería de Lulio en el Libro del amigo y del Amado. Mi intención era, y es, poner de relieve algunas imágenes del libro especialmente significativas desde mi punto de vista. Me doy cuenta de que un estudio a fondo, sistemático, del libro, exigiría examinar todas y cada una de las metáforas muy detenidamente, anotando las correlaciones, las interacciones y las conexiones de diverso tipo de unas con otras y con el resto de la obra luliana, para al final intentar establecer unas tipologías determinadas, intento en ningún caso fácil, como advierte Lola Badía. Para abrir boca, yo me conformo con seleccionar algunas que han llamado mi atención.

\subsection{La gran imagen}

En el Libro del Amigo y del Amado la gran imagen, que llena la obra, y a la que se supeditan todas las demás, es la constituida por el cristiano amigo y el Dios Amado. El cristiano representa el sujeto y Dios el objeto, a la contra de lo que significa ser creado: objeto, y ser creador: sujeto de la acción. Se vuelven las tornas. La razón es que Lulio se sitúa en la perspectiva del hombre; ve, siente, ama, oye, habla, gusta, huele, discurre desde el hombre. Y su mística no es la de abandonarse en el Amado, dejarse llevar por el Amado, sino caminar al encuentro del Amado. Su mística no es dejarse conquistar por Dios, sino conquistar a Dios. De ahí que la gran imagen es el amigo como sujeto activo, de cara al Amado como objeto pasivo. Diferente, entiendo, del misticismo castellano de santa Teresa, de san Juan de la Cruz y de fray Luis de León, en el que el Amado toma la iniciativa mística (no entro en la ascética preparatoria) y lleva al amante hacia si; en el que el amigo es subido, es llevado hacia el Amado por el Amado. En esta obra de Lulio el amigo camina, corre hacia el Amado, se eleva hasta el Amado; un misticismo dinámico frente a un misticismo estático, si bien ambos cuentan con la ayuda, la gracia, del Amado y tienden a acabar en el gozo contemplativo.

Lulio representa a través de la imagen del amigo y del Amado la vida del cristiano en la tierra como valle de lágrimas y de esperanza, con todos los ingredientes: pensamientos, deseos, trabajos, tribulaciones, caídas [olvidos], satisfacciones [cuando el amigo se da cuenta del Amado, cuando percibe su presencia, sus dones], pruebas de fe, que le fortifican en la fe, en la espera y en el amor. Lo quiere hacer al estilo de como lo hacían los sufies, mediante ejem- 
plos breves [imágenes, metáforas], que son palabras de amor [oraciones breves: jaculatorias], con el deseo y la pretensión de despertar en el hombre cristiano gran devoción ${ }^{13}$. Adviértase la plasticidad de la expresión luliana. La imagen se hace palabra en el que escribe y la palabra lleva a la imagen en el que lee. El lector va de la palabra a la imagen, pero el escritor va de la imagen a la palabra; el escritor imagina y expresa, mientras que el lector ve, lee, imagina y comprende.

Es de admirar lo que se inventa Lulio en un asunto tan singular, en el que no desarrolla más que variaciones sobre el mismo tema: amigo-amor-Amado, tema que se resume en que el amigo sufre de amor, con amor y por amor, a la vez que goza, no solamente del Amado (en memoria, entendimiento y voluntad: recordar, conocer y amar, pero no en posesión), sino del propio sufrimiento por el Amado, donde alcanza un cierto grado de lo que me atrevería a calificar como masoquismo místico, en el que el Amado se complace del amigo, del amigo que sufre de amor. El lazo de unión entre amigo y Amado no es la amistad, sino el amor. El trío de términos entra, conjunta o separadamente, en todas las metáforas del libro.

Lulio procura no dejar nada al margen, fuera de la memoria, en el olvido. Precisamente, el olvido es lo realmente contrario al amor, que es el protagonista del libro, porque, a fin de cuentas, el amor es todo lo que hay, absoluta y simplemente, entre amigo y Amado; lo demás es accesorio, es solamente el instrumento para comprender que el todo es el amor de amigo y Amado. Mientras el amor está activo en la memoria, no hay trabajos, deseos, pensamientos, fatigas, tribulaciones, que no sean elementos positivos; son componentes del amor en el amigo, demostración y presencia del amor del amigo en el Amado, el cual envía placer al amigo en la tribulación y en la fatiga.

\subsection{Otras imágenes}

Todas las demás imágenes están subordinadas a la principal, de modo que se utilizan en apoyo de la relación amigo-Amado, sirven de vehículo al amor, que es lo que une los términos amigo y Amado. Las imágenes tienen un cometido trascendente; tienen que llevar de lo creado al creador, de lo material a lo espiritual, de lo meramente sensible a lo inteligible por la fe, de lo inmanente a lo trascendente. Y en este camino, la razón humana juega menos, puesto que no alcanza la distancia; se utilizan imágenes para salvar la razón, para saltar por encima de ella, para hacer ver razonable aquello que la razón no puede captar por si misma a través de un razonamiento puramente lógico.

\subsubsection{La vida del amigo es caminar hacia el Amado}

En dieciséis metáforas nos habla Lulio del camino, de los caminos, de encaminarse ${ }^{14}$, y en muchas otras aparece la idea de estar y andar en el camino; el amigo va, anda, viaja, pasea, busca, encuentra, está en ${ }^{15}$. El camino es a un tiempo: camino del amigo, que va solo o acom-

13 En De cómo Blanquerna, ermitaño, hizo el «Libro de amigo y Amado», que es pieza anterior al prólogo: «Mientras reflexionaba de esta suerte, Blanquerna recordó que una vez, cuando era papa, le había referido un sarraceno que entre ellos hay ciertos hombres religiosos, los más apreciados de todos, que se llaman sufíes, que poseen palabras de amor y ejemplos abreviados que despiertan en el hombre gran devoción; y son palabras que precisan de exposición; y mediante la exposición el entendimiento se eleva más hacia lo alto, elevación por la cual la voluntad se multiplica y asciende en devoción». En la metáfora 153, Lulio hace referencia a otra costumbre musulmana digna de ser imitada por los cristianos: «Vituperaba el amigo a los cristianos porque no ponen el nombre de su Amado, Jesucristo, en el principio de sus cartas, a fin de darle la honra que los sarracenos otorgan a Mahoma, que fue hombre engañador, al cual dan honra al mencionarlo al principio de sus cartas».

14 Números: 2, 4, 35, 39, 69, 89, 109, 111, 149, 154, 166, 313, 328, 345, 351, 356.

15 Números: 5 (venir a ver), 21 (ir a beber), 139 (ir a combatir), etc. 
pañado; camino del Amado, que lleva al Amado, en el que el amigo dialoga con el Amado, en el que siente y olvida al Amado; camino del amor, en cuanto el amor es el contenido del camino; sin amor desaparecería el camino, no tendría sentido.

Además, Lulio introduce algunas referencias a los fenómenos de la peregrinación-romería, de la hospitalidad y de la acción misionera, pero no como un asunto recurrente; más bien, de forma ocasional, aunque el espíritu misionero aparece al menos en nueve ocasiones, lo que no es extraño, dada su preocupación, tan conocida, en este sentido ${ }^{16}$.

La imagen más recurrente es la de que el camino es la vida del amigo hacia el Amado. El camino evoca idea de movimiento, de acción: ir, venir, andar, pasear, subir, etc. Camino es, a veces, simplemente el viaje de la vida; a veces, es la forma de amar; en ocasiones tiene sentido material, geográfico, de lugar; pero, sobre todo, tiene un sentido formal: el camino es el amor del amigo que lleva al Amado.

Observo en Lulio dos caminos imaginativos: sensorial e intelectivo. El primero se hace presente al entendimiento y a la voluntad a través de la percepción sensorial; la imagen formada pasa al entendimiento y a la voluntad. El otro se forma a través de la memoria, del recuerdo, trayendo el objeto (el Amado, sus facciones, sus cualidades, su amor...) y presentándolo al entendimiento, como una especie de revival, que multiplica el efecto de lo percibido por los sentidos. En ambos casos, la imaginación y la memoria (que se porta como motor de la imaginación intelectiva, no sensorial) son los ejes del sistema.

Desde el punto de vista de la percepción sensorial, Lulio insiste en la dureza y en los peligros del camino. Lo predica ya desde el principio. En la metáfora número 2 los caminos por los cuales el amigo busca al Amado son largos y peligrosos; en la número 4 se habla de caminos infernales, que el amor convierte en seguros y livianos; en la 35 las espinas del camino son flores para el amigo; en la 69 los caminos son largos y breves; en la 109 las quejas de un amador sobre el camino revelan momentos de debilidad del amigo; en la 111 dos leones asaltan al amigo; en la 119 un león feroz aparece en el camino; en la 149 hay enemigos en el camino; en la 166 el amigo cae prisionero en el camino; en la 328: los caminos estrechos responden a amores anchos y viceversa; en la 345 el camino, de por si largo, duro y áspero, se convierte en liviano por amor.

Desde el punto de vista de la percepción intelectiva, el camino está marcado sobre todo por el amor; mejor aún, el amor es, en verdad, el camino. En la metáfora 39 el camino es vía de tránsito hacia el Amado, es camino de la vida ${ }^{17}$; en la 89 los caminos son modos de llegar al corazón del Amado, de amar; en la 154 el amigo encuentra la ayuda de un escudero, que es otro amador, para dar con el camino hacia el Amado; en la 313 señala los caminos que conducen hacia el Amado: vegetación, sentimiento, imaginación, entendimiento, voluntad; en la 351 anota dos tipos de caminos como modos válidos y no excluyentes para llegar al Amado: vías sensuales y rutas intelectuales; y abre, pero no cierra, la discusión sobre qué vías se utili-

16 Números: 212 y 230 (peregrinación), 101 (hospitalidad), 166, 212, 215, 217, 263, 320, 322, 331, 336 (espíritu misionero).

17 El Cantar de los cantares es, sin duda, una de las fuentes principales en las que se inspira Lulio. Aquí, en concreto, evoca la búsqueda del Amado por la esposa (Cc 3, 1-4; y 5, 5-8). Metáfora 39: «Levantóse de mañana el amigo, y buscaba a su Amado; encontró gente que iba por el camino, y les preguntó si habían visto a su Amado. Respondiéronle preguntando en qué hora su Amado se ausentó de sus ojos mentales. Contestó el amigo y dijo: Desde que hube visto a mi Amado en mis pensamientos, nunca estuvo ausente de mis ojos corporales, pues todo lo visible me representa a mi Amado». Cantar de los cantares, 3, 1-4: «En el lecho, entre sueños, por la noche, busqué al Amado de mi alma, busquéle y no le hallé. Me levanté y recorrí la ciudad, las calles y las plazas, buscando al Amado de mi alma. Busquéle y no le hallé. Encontráronme los guardias que hacen la ronda en la ciudad: ¿habéis visto al Amado de mi alma? En cuanto de ellos me aparté halle al Amado de mi alma...». Cantar de los cantares, 5, 5-8: «Me levanté para abrir a mi Amado... Abrí a mi Amado, pero mi Amado se había ido, desapareció... Le llamé, mas no me respondió. Encontráronme los guardias que rondan la ciudad... Os conjuro, hijas de Jerusalén, que si encontráis a mi Amado le digáis que desfallezco de amor». 
zan primero y cuáles prefiere el Amado, con lo que parece dar la misma importancia a ambas, probablemente porque a Lulio le interesa el fondo del asunto, que es estar en el camino hacia el Amado, y no tanto el modo de que se sirve el amigo para estar en él; en la 356 el camino es una vía de tránsito con gran concurso de gentes, cuya curiosidad no satisface el amigo, que camina absorto pensando placenteramente en el Amado; en la 357 el amigo camina en busca del Amado revestido de amor por dentro y por fuera.

\subsubsection{Locura de amor}

Lulio insiste bastante en la consideración del amor como locura por parte del amigo. Es locura el amor del amigo y es loco el amigo mismo. Hasta en 47 metáforas $(12,87 \%)$ se alude de manera expresa a la locura de amor del amigo ${ }^{18}$. Si a través de otras metáforas pudiéramos dudar si estamos o no ante un libro realmente autobiográfico, a través de las metáforas que se refieren a la locura de amor del amigo nos queda claro que el retratado es el propio Raimundo Lulio. Lo da por sabido Martín de Riquer cuando lo toma como criterio para la traducción del término «foll»: «De los dos sentidos que tiene la palabra foll, «necio» y «loco», en esta expresión luliana, tan frecuente en el Llibre d'Amic e Amat, el que conviene es el segundo, pues Llull se considera presa de la locura del amor divino y en algún pasaje de sus obras se llama a sí mismo Ramon lo foll $\gg{ }^{19}$.

El recurso de Lulio a la locura de amor tiene dos vertientes desiguales: el ser y el estar. De una parte, la locura afecta al amigo, al amador, en si mismo; el amigo, el amador, es loco. Por èllo, puede denominarle loco sin más, como si fuera su nombre: «Dí, loco» o «Amigo, loco». Es la vertiente preferida por Lulio y a ella afectan la mayor parte de las referencias. No importa en el caso el contenido de la metáfora; la locura del amigo es un hecho y la denominación de loco no es más que una variedad para nombrar al amigo, un recurso literario, que le permite a un tiempo recordar que su amor es locura y destacar la equivalencia de amigo y loco. De otra parte, la locura afecta al amigo, al amador, en su comportamiento. En este sentido, se dice de él que está loco porque se comporta como loco: no se atiene a reglas, no ve peligros, llega más lejos de lo que exige la sensatez racional al uso, va como loco, la gente lo ve pasar como loco. Esta segunda vertiente aparece pocas veces; de las 47 referencias anotadas, sólo cuatro dicen relación a andar, a comportarse ante la gente como loco ${ }^{20}$. Se trata evidentemente de vertientes conectadas; conectadas por el amor: se es loco por ser amador, y se está loco por la acción de amar; el estar loco es una consecuencia, por lo demás lógica, de ser loco.

La locura de amor que Lulio expone apunta, y lo he señalado anteriormente, a un cierto masoquismo místico; el ser loco por amor significa sufrir por amor, y la multiplicación del sufrimiento se convierte en motor que multiplica el amor. Hay placer en el dolor; y sólo en el deseo y en la esperanza de la meta, meta que queda fuera de la obra, se ve que el amor está destinado a ser posesión feliz entre amigo y Amado; pero en tanto que no se alcanza la meta, el amor es sólo sufrimiento feliz. No se contradice esta conclusión con la idea expresada en la metáfora inicial, en la que el Amado, a la pregunta del amigo de «si quedaba en él algo por amar», responde: «que aquello por lo que el amor del amigo podía multiplicarse era por amar», pues el contenido de ese amar no es otro que deseos, fatigas, llantos, pensamientos, sufri-

18 Números: 11-12-53-62-65-68-72-73-74-78-83-92-147-157-160-161-175-176-178-180-182-189-199-202211-214-235-238-241-242-245-253-254-262-280-283-286-287-289-291-292-294-354-358-359-362-365.

19 Ramon Llull. Libro de amigo y Amado, obra citada, p. 13, nota 1. La metáfora anotada es la número 12 de esta edición, pero para nosotros es la número 11, según lo dicho en la nota 8 . Es la primera en la que Lulio llama loco al amigo.

20 Números 53: «Iba el amigo por una ciudad como loco ...»; 147: «Escarnecía y reprendía la gente al amigo porque iba como loco por amor ...»; 157: «... y la vergüenza que siente el amigo de andar ante la gente como loco...»; 175: «Di, hombre que vas como loco por amor...». 
mientos, suspiros, trabajos, etc., como lo hace ver el propio Lulio a lo largo de todo el libro' ${ }^{21}$. Es la unidad de los opuestos en la culminación mística, representada muy bien en la metáfora número siete, donde afirma que la prueba del amor no es el reconocimiento de una gracia, de un don del Amado, sino la ceguera, la locura, con que el amigo ama al Amado, al entender como gracia el no hacer diferencia entre los sufrimientos y los consuelos que le envía el $\mathrm{Amado}^{22}$. Lulio utiliza mucho los contrastes para dar fuerza a las imágenes; se trata de potenciar la llamada de atención al lector.

\subsubsection{Sensibilización de las potencias del alma racional}

Las referencias a las potencias del alma racional son muy numerosas, especialmente a la memoria. Detenerse en ellas sería interminable; cuando menos, habría que ir glosando las referencias una a una, lo que, en la práctica, supondría elaborar una edición glosada del texto luliano, empresa sin duda loable y útil, pero que no es el objeto de estas líneas. Unos datos estadísticos aproximativos nos dan el resultado siguiente.

Desde la perspectiva de la memoria (recuerdo, recordar, olvido), ésta aparece de una u otra forma en 72 metáforas ${ }^{23}$. En 14 de ellas la memoria conjuga con el entendimiento y la volun$\operatorname{tad}^{24}$; en 17 conjuga la memoria con el entendimiento, a solas ${ }^{25}$; en 2 conjuga la memoria con la voluntad, también a solas ${ }^{26}$. En el resto, o sea en 39 , la memoria ocupa toda la metáfora ${ }^{27}$.

En cuanto al entendimiento (entender, conocer, comprender, ignorar), éste aparece en 61 metáforas ${ }^{28}$. Además de las 14 en que conjuga con la memoria y la voluntad, y de las 17 en que conjuga con la memoria a solas, en 9 conjuga el entendimiento con la voluntad ${ }^{29}$. En el resto, o sea en 21 , el entendimiento ocupa toda la metáfora ${ }^{30}$.

La estadística de la voluntad (como decisión de hacer o no hacer algo) aporta los datos siguientes. Aparece en 46 metáforas ${ }^{31}$. Como he señalado, conjuga con la memoria y el entendimiento en 14 metáforas; en 9 con el entendimiento, a solas; y en dos, también a solas, con la memoria. En el resto, o sea en 21 , la voluntad ocupa toda la metáfora ${ }^{32}$.

Consideración aparte merecen las referencias a los pensamientos. Hasta en 69 metáforas introduce esta expresión, que utiliza para significar imágenes mentales, preocupaciones, ideas, deseos. Unas veces se conecta con la memoria, otras con el entendimiento y otras con la voluntad o con los sentidos. Puede ser un recuerdo de la memoria; o un resultado de la potencia

21 Número 1: «Preguntó el amigo a su Amado si quedaba en él algo por amar; y el Amado respondió que aquello por lo que el amor del amigo podía multiplicarse era por aman»

22 Número 7: «Preguntó el Amado al amigo: ¿Recuerdas alguna cosa con la que te haya recompensado porque me ames? Respondió: Sí, porque entre los trabajos y los placeres que me das, no hago diferencia alguna».

23 Números: 6-7-16-17-27-39-52-53-54-58-59-65-68-69-78-88-91-102-106-107-111-121-126-127-130-133136-137-138-167-168-183-187-188-192-193-194-196-199-203-205-207-209-217-218-225-230-244-245-248-253273-282-297-304-315-316-318-319-326-330-333-334-336-337-338-340-341-342-347-363-364.

24 Números: 53-102-106-126-130-138-168-183-192-225-297-330-334-347.

25 Números: 6-52-78-91-107-121-133-137-188-196-205-217-253-304-336-337-363.

26 Números: 127-318.

27 Números:7-16-17-27-39-54-58-59-65-68-69-88-111-136-167-187-193-194-199-203-207-209-218-230-

244-245-248-273-282-315-316-319-326-333-338-340-341-342-364.

28 Números: 6-18-26-52-53-78-91-102-106-107-121-122-126-130-133-135-137-138-142-152-154-160-161164-168-177-178-183-188-192-196-197-205-208-214-217-225-240-246-253-263-286-287-297-300-304-313-320$330-331-334-335-336-337-347-349-353-355-361-362-363$.

29 Números: 18-122-135-160-240-313-320-331-353.

30 Números:26-142-152-154-161-164-177-178-197-208-214-246-263-286-287-300-335-349-355-361-362.

31 Números: 18-53-102-106-122-126-127-130-135-138-160-163-168-170-183-184-192-195-202-212-219 -

220-221-225-226-235-240 - 243-247-270-279-285-297-306-309-310-313-317-318-320-322-330-332-334 -347-353.

32 Números: 163-170-184-195-202-212-219-220-221-226-235-243-247-270-279-285-306-309-310-317-322. 
intelectiva, una idea; o bien, un acto de la voluntad, un regalo de amor, un deseo; o unos ojos que lloran ${ }^{33}$.

El amor muere de olvidos y vive de pensamientos ${ }^{34}$; o sea, el amigo está con el Amado en tanto que lo tiene en sus pensamientos ${ }^{35}$, en tanto que la memoria presenta al amigo las facciones del $\mathrm{Amado}^{36}$. Con frecuencia, el término va unido al conjunto de las muestras de amor que el amigo recibe y ofrece; le acompañan suspiros y lloros, fatigas y trabajos, placeres y deseos, llantos y tribulaciones ${ }^{37}$. La interrelación es tal que el amigo puede comprar «un día de llantos por otro día de pensamientos» y puede vender «un dia de amores por otro de tribulaciones», consiguiendo así multiplicar «sus amores y sus pensamientos» ${ }^{38}$. Mientras el amigo prepara para el Amado un lecho de pensamientos, un lecho de amores ${ }^{39}$, el Amado viste al amigo con una camisa de pensamientos ${ }^{40}$. El amigo narra con lágrimas la pasión soportada por el Amado y escribe con tristeza y pensamientos las palabras que dice ${ }^{41}$. Los pensamientos llegan al corazón del amigo para elevar el agua a los ojos ${ }^{42}$. Los amores del amigo y del Amado, que se anudan con memoria, entendimiento y voluntad, se atan con una cuerda hecha de pensamientos, fatigas, suspiros y $\operatorname{llantos}^{43}$.

No es mi propósito entrar en las funciones e interrelaciones de las potencias racionales en el sistema luliano ${ }^{44}$; simplemente, destacar la sensibilización de las mismas ${ }^{45}$. Por medio de imágenes, Lulio halla el modo de pasar de lo inteligible a lo sensible, y de lo sensible de nuevo a lo inteligible, hasta el punto de que Lulio parece no querer que el lector elija entre las vías sensuales y las rutas intelectuales, dado que para el fin ambas le sirven igualmente. Así, en la metáfora número 17 se establece una discusión entre los ojos [vía sensual] y la memoria [ruta intelectual], sin que Lulio despeje la incógnita de qué es lo mejor: si ver al Amado o recordarlo; y en la número 351 , cuando el amigo va lloroso [ojos] y acongojado [mente] en busca del

33 Números: 3-16-24-35-39-40-47-59-63-68-69-70-78-86-87-97-99-104-105-112-115-124-125-130-132-135140-141-148-155-166-167-171-172-176-181-219-223-224-228-229-230-231-233-239-242-249-252-253-259-275281-292-295-298-299-300-302-304-306-316-322-329-332-342-345-355-356-358.

34 Número 16: «Entre amor y esperanza ha hecho su habitación amor, donde vive de pensamientos y muere de olvidos...».

35 Número 24: «... ¿Cuánto estarás con tu Amado? Tanto tiempo cuanto estén en él mis pensamientos».

36 Número 88: «... El Amado hizo volver en sí al amigo cụando le recordó sus facciones».

37 Por ejemplo, números: 47-63-78-99-105-112-130-135-140-155-166-167-176-181-219-231-242-302-329.

38 Número 332.

39 Número 230 («.... y su amigo le dispuso lecho de pensamientos...»), que cabe combinar con números 35 («... y le pareció... que su lecho era de amores») y 281 («Edificaba y construía el amigo una hermosa ciudad donde morase su Amado. Con amor, pensamientos... la construía...»).

40 Número 132: «Vestía el Amado a su amigo... y hacíale sombrero de amor, camisa de pensamientos...».

41 Número 275: «Con lágrimas en los ojos narraba el amigo la pasión y el dolor que su Amado soportó por su amor; y con tristeza y pensamientos escribía las palabras que decía; y con misericordia y esperanza se consolabas.

42 Número 171: «Devoción y nostalgia enviaron pensamientos, por mensajeros, al corazón del amigo, a fin de que elevase el agua a los ojos, los cuales querían detener el llanto en el que hacía mucho tiempo que perseveraban».

43 Número 130: «Anudábanse los amores del amigo y el Amado con memoria, entendimiento y voluntad, a fin de que el amigo y el Amado no se separasen; y la cuerda con que se anudaban los dos amores era de pensamientos, fatigas, suspiros y llantos».

44 Con relación al tema de la relación de amor del amigo y del Amado, de entre las varias metáforas que sintetizan su tesis, cabe citar la número 91: «Ausentóse el Amado de su amigo, y el amigo buscaba a su Amado con memoria y con entendimiento a fin de poderlo amar. Halló el amigo a su Amado; preguntóle dónde había estado. Respondió: En la ausencia de tu memoria y en la ignorancia de tu inteligencia».

45 Esteve Jaulent, en el primer apéndice (p. 134) de su edición brasileña de lä obra de Lulio, Livro do amigo e do Amado (Edições Loyola, São Paulo, 1989), basada en la edición de Joan Pons i Marqués (Obres Essencials, vol. I, Barcelona, 1957), con relación a la potencia racional [o alma racional], afirma que en la teoría luliana las cosas y las acciones están antes en el entendimiento, como en potencia, pero que sólo son bien conocidas cuando son sentidas, cuando han pasado por los sentidos. Es decir, que los conceptos no obtienen su perfección sin los sentidos. 
Amado por vías sensuales y por rutas intelectuales, no responde a la pregunta sobre «en cuál de los dos caminos entró primero mientras buscaba a su Amado, y en cuál el Amado se mostró más declaradamente al amigo», y se conforma con señalar que «se discute».

Con el juego de imágenes, Lulio construye argumentos lógicos y elabora pensamientos del corazón, pronuncia palabras de amor, ama y se entiende sin palabras: con lágrimas, guiños, cantos, señas de amor ${ }^{46}$. Y no es sorprendente, aunque pueda parecerlo en un primer momento, que en el Libro del amigo y del Amado, tan pleno de imágenes, apenas se hagan referencias expresas a la imaginación. La razón es que Lulio está trabajando de continuo con ella, la emplea en cada metáfora, en cada verbum cordis ${ }^{47}$. Realmente, está en todas, aunque sólo se mencione en algunas de modo explícito ${ }^{48}$.

La sensibilización de la memoria, que es la potencia a la que más recurre Lulio, deriva de su función retenedora de imágenes. Lo suyo es recordar, hacer presente al Amado o que el Amado se haga presente. En cierto modo, la memoria es el instrumento principal en el juego del amor, y va unida a la imaginación, a las facciones del Amado. El Amado muestra sus facciones a la memoria y al entendimiento del amigo, y se da a la voluntad como objeto, se convierte en objeto de amor ${ }^{49}$. El amigo busca al Amado con memoria y entendimiento para poderlo $a_{m a r}{ }^{50}$. La memoria siempre en primer término porque es el recuerdo, es la presencia, es el amor, es la vida ${ }^{51}$.

La memoria juega un cometido hasta cierto punto imaginativo, en cuanto que aporta al entendimiento y a la voluntad las facciones del Amado, la imagen que retiene del Amado, de modo que éste sea reconocido por el amigo. Recordar es sentir de nuevo la presencia del Amado, es ver, oír, hablar de nuevo al Amado; es volver a gustar de sus facciones; y con efecto multiplicador ${ }^{52}$.

46 Corazón y amor están hechos para amar y pensar. En la metáfora 73 afirma la coexistencia del corazón y del amor. De lo contrario «el corazón no hubiera sido creado para amar, ni el amor hubiera sido creado para pensar». En la metáfora 209 el corazón del amigo cesa de pensar sin recordar a su Amado». El amor es «presencia de facciones y palabras del Amado en suspirante corazón de amadon» (metáfora 169). Cabe citar también las metáforas $28,34,37,40,47,57,78,172,174,185,275,281$, entre otras, donde Lulio se sirve de juegos de imágenes para expresar la relación de amor entre amigo y Amado, con mezcla de rutas sensitivas e intelectivas.

47 En la metáfora 28 dice el amigo al Amado que le basta un guiño por toda palabra: «No es preciso que me hables, sino hazme sólo una seña con los ojos, que para mi corazón son palabras, a fin de que te dé lo que me pides».

48 Solamente las metáforas 313: «Por caminos de vegetación, de sentimiento, de imaginación...», y 331: «El amigo pintaba y modelaba en su imaginación las facciones de su Amado en las...», hacen referencia explícita a la imaginación. El verbo imaginar se conjuga en las metáforas 111: «lba el amigo por una tierra extraña en la que se imaginaba encontrar a su Amado...», 146: «El amigo se imaginaba...», y 227: «No se imagine mi Amado... no se imagine mi amigo...», según la traducción de Planeta, que utilizo aquí, pero con un significado entiendo que más amplio de: pensar. La magnífica edición brasileña del Livro do amigo e do Amado a cargo de Esteve Jaulent, citada en nota 45, traduce en el primer caso [se imaginaba encontrar] por procurar: «e procurava seu Amado...», y en los otros dos por pensar: «O amigo pensava», «Não pense meu Amado ... Não pense meu amigo...».

49 Número 106: «... y el Amado mostró sus facciones a la memoria y al entendimiento del amigo, y diose a la voluntad por objeto».

50 Número 91: «... y el amigo buscaba a su Amado con memoria y con entendimiento a fin de poderlo amar».

51 Números 6: la presencia del Amado es conocimiento y recuerdo; la ausencia es ignorancia y olvido; 16 : el amor vive de pensamientos y muere de olvidos; 27: el amigo llora para no dormir y así no olvidar a su Amado; 54: es contra el amor que el amigo duerma, olvidando al Amado, y que el Amado no despierte al amigo; 61: desamor es muerte, amor es vida; 137: el amor nace en el recuerdo, vive en la inteligencia y muere en el olvido. Con otras muchas metaforas que inciden en esta idea.

52 Libro del amigo y del Amado, metáfora 168:«Encontró el amigo a su Amado. Conoció el amigo a su Amado, y lloró. Reprendió el Amado a su amigo porque antes de haberlo conocido no lloraba, y le preguntó en qué lo había conocido, puesto que no lloraba. Respondió el amigo que en la memoria, en el entendimiento y en su voluntad, en lo que hubo aumento así que estuvo presente a sus ojos corporales»; y metáfora 192: «La tentación se acercó al amigo con intención de ausentarlo de su Amado, y a fin de que la memoria se despertase y recobrase la presencia de su Amado, recordándolo más vivamente de lo que lo había recordado, para que el entendimiento se elevase más para entender a su Amado, y la voluntad para amarlo». Los ejemplos podrían multiplicarse. 
Por medio de los sentidos llega el amigo al recuerdo [imagen grabada en la memoria], a la intelección y al amor [voluntad] del Amado; y, a su vez, la voluntad, el entendimiento y la memoria llaman a los sentidos para que hagan presente al Amado, y así captarlo y amarlo. Lulio utiliza los conceptos como si fueran cosas materiales, los hace imágenes sensibles y los personaliza. Memoria y entendimiento son el medio de transporte en que viene amor, con facciones, honores y valores del Amado de equipaje ${ }^{53}$. Entendimiento y voluntad echan a correr, compiten en una carrera para ver quién llega antes al $\mathrm{Amado}^{54}$, y debaten sobre el amor ${ }^{55}$. Todo lo visible representa al Amado; si el Amado está en los ojos mentales del amigo, lo estará también en sus ojos corporales ${ }^{56}$.

¿Cómo se comporta en este juego la imaginación? Desempeña, sin duda, un papel muy importante, axial, en la sensibilización de las potencias superiores del alma racional. La imaginación, como potencia injertada en la sensitiva, de la que saca semejanzas, al igual que de la vegetativa y de la elementativa, no puede llegar al alma racional ${ }^{57}$; a pesar de lo cual, Lulio sitúa la imaginación al lado del entendimiento y de la voluntad. Estas tres potencias poseen la mano que maneja el martillo y el clavo del martillo $0^{58}$. No se trata de equiparar las potencias ni de confundirlas, por supuesto; sería cosa de necios ${ }^{59}$; se trata de que la imaginación funciona de eje entre el mundo sensible y el inteligible. El entendimiento es señor de la imaginación y, como tal, la posee y "se sirve de ella para imaginar las cosas corporales» ${ }^{60}$. El recorrido de los sentidos, y muy en especial de la vista, hasta el entendimiento, la memoria y la voluntad, pasa por la imagiriación. En la práctica, Lulio convierte a la imaginación en el eje del proceso del conocimiento. Así lo da a entender en Proverbis, donde afirma: «Lo que el entendimiento toma de lo que la imaginación ha recibido de los ojos, la memoria lo presenta a la voluntad ${ }^{61}$; y en Libro del amigo y del Amado, metafora 313, donde dice que: «Por caminos de vegetación, de sentimiento, de imaginación, de entendimiento y de voluntad, iba el amigo en busca de su Amado».

El sentido de la vista es el más destacado. He contabilizado 68 referencias para la vista [ver, ojos, mirar, lágrimas, llantos, llorar $]^{62}$. El amigo puede decir que el Amado es ojos de sus

53 Número 78: «... ¿Qué te trajo amor? Hermosas facciones, honores y valores de mi Amado. ¿En qué llegaron? En memoria y en entendimiento...».

54 Número 18: «Preguntó el amigo al entendimiento y a la voluntad cuál de ellos estaba más cerca de su Amado, y ambos echaron a correr, y el entendimiento llegó antes a su Amado que la voluntad». El hecho de que Ilegue antes el entendimiento nos trae a la memoria la bien conocida sentencia: nihil volitum quin precognitum, que en versión vulgar podría traducirse por: ojos que no ven, corazón que no siente, y que, a su vez, nos refuerza en la importancia de la imaginación, como conformadora y portadora de lo sensible.

55 Número 353: «La voluntad del amigo se amaba a sí misma, y el entendimiento le preguntó... Y por esto se discute sobre qué respuesta pudo dar más verdaderamente la voluntad al entendimiento».

56 Número 39: el amigo pregunta a la gente si han visto a su Amado. La respuesta es una pregunta: ¿En qué hora se ausentó el Amado de sus ojos mentales? Entonces el amigo responde: «Desde que hube visto a mi Amado en mis pensamientos, nunca estuvo ausente de mis ojos corporales, pues todo lo visible me representa a mi Amado».

57. Ramon Llull. Proverbis de Ramon. Edición preparada por Sebastián Garcías Palou, Editora Nacional, Madrid, 1978, capítulo 191, número 3 [p.320]: «La imaginativa es injertada en la sensitiva y saca de ella semejanzas, lo mismo que de la vegetativa y de la elementativa; y capítulo 192, número 10 [p.323]: «Ni la sensitiva ni la imaginación pueden llegar al alma racional».

58 Ibid. Capítulo 250, número 11 [p.405]: «La voluntad, el entendimiento y la imaginación poseen la mano que maneja el martillo, el cual es poseído de aquélla, y el clavo del martillo».

59 Ibid. Capítulo 299, números 13 y 16 [p. 463]: «Todo aquel que se deja llevar de la imaginación más que del entendimiento, es necio»; «El hombre necio confunde la imaginación con la inteligencia».

60 Ibid. Capítulo 250, número 10 [p. 405].

61 Proverbis de Ramón, capítulo 257, número 8 [p. 414].

62 Números:5-7-17-18-20-23-27-28-37-39-40-44-46-47-48-58-77-78-80-88-89-95-103-105-109-116-124125-126-128-130-131-145-148-151-152-166-168-171-172-174-176-181-185-209-212-228-230-232-233-252-281286-295-310-321-329-332-336-344-348-349-350 [la teología lloraba] -351-355-359-363-364 
ojos $^{63}$; y en su testamento hay un legado para los ojos, junto a corazón-voluntad, entendimiento y memoria ${ }^{64}$. Tan alto grado de personalización no se aplica a los otros sentidos. El sentido de la vista lo conecta de modo especial con el entendimiento ${ }^{65}$. De otra parte, parece claro que Lulio deposita más confianza en la vista que en el oído, más en la lectura que en la escucha de una predicación oral, quizá, justamente por la relación estrecha que tiene con el entendimiento ${ }^{66}$.

\title{
3. CONCLUSIÓN
}

A través del Libro del amigo y del Amado, el lector constata que el amigo mantiene el amor en un hervidero de sensaciones en un continuo fluir de la potencia sensitiva a la raciocinativa a través de la potencia imaginativa. Es de sobra conocido, y queda claro en este libro, que las formas, los instrumentos, le importan poco a Lulio; simplemente, los utiliza. Lo que le importa es destacar el tema de fondo, que es saberse en cada momento en búsqueda del Amado por vías sensuales y por rutas intelectuales, indistintamente ${ }^{67}$. Y con este pretexto llena de imágenes a sus lectores.

Hay en esta obra de Lulio una espiritualización de lo sensible y una sensibilización de lo inteligible. Es este segundo aspecto el que he pretendido destacar en estas reflexiones.

\author{
José María Soto Rábanos \\ Instituto de Historia.CSIC. \\ Duque de Medinaceli, 6 \\ 28014 Madrid \\ E-mail: jmsoto@ceh.csic.es
}

63 Número 295: «... ¿Qué deseas, Amado, que eres ojos de mis ojos...?».

64 Número 336: «Enfermó el amigo, e hizo testamento con el consejo de su Amado. Los pecados y las culpas los dejó a...; a sus ojos dejó llantos, y a su corazón, suspiros y amores; a su entendimiento dejó las facciones de su Amado; a su memoria...».

65 El entendimiento ve, dice en las metáforas 334: «Oía el amigo palabras de su Amado, y en ellas lo veía su entendimiento...», y 335: «Oía el amigo vituperar a su Amado, y en ese vituperio el entendimiento veía...».

66 Aparte las referencias ya señaladas a su afán misionero, cabe destacar sus referencias a libros; de ellas creo que la principal está en la metáfora 286, en la que remite a las «diez condiciones del Libro del gentil y de los tres sabios» para responder a la pregunta de en qué conoce el amigo [nominado aquí: loco] que la fe católica es verdadera y la de judíos y sarracenos falsa. Otras referencias librarias en las metáforas: 13 [el Amado lee un libro de dolencias y satisfacciones del amigo]; 14 [posible referencia al Libro de Santa Maria del propio Lulio, y así lo anota Martín de Riquer]; 86 [libro místico de las facciones del Amado]; 142 [el gran libro que Lulio se propone: El Arte, que fue componiendo en distintas fases] 228 [libro en el que están escritos los bienaventurados].

67 Metáfora número 351. 